\title{
The Gospel of Thomas and the Platonists on the Body and the Soul
}

In this chapter, I would like to discuss the Thomasine views on the nature of the human soul and its relationship with the body. I will mainly discuss sayings 29 , 87 , and 112. I will argue that the Gospel of Thomas does not adhere to the tripartite anthropological model. In my opinion, sayings 29,87 , and 112 , while using different terms ("soul" vs. "spirit"), express the same idea of body-soul dualism. I will also argue that, while the importance of Platonism for the understanding of Thomasine anthropology can hardly be overestimated, saying 112 should not be read as a concise paraphrase of Tim. 87c-89a. A much more viable option is to read this saying against the background of Phaed. 64a-7ob.

In what follows, I will briefly present the sayings that appear to be crucial for this discussion-viz., sayings 29,87 , and 112. I will then focus on the terminology employed in these sayings and ascertain whether the Gospel of Thomas distinguishes the flesh $(\sigma \alpha \dot{\rho} \xi)$ from the body $(\sigma \hat{\omega} \mu \alpha)$, and the soul $(\psi v \chi \eta \dot{\eta})$ from the spirit $(\pi \nu \varepsilon \hat{\nu} \mu \alpha)$. My answer to both questions will be in the negative: Thomasine anthropology is bipartite; the only anthropological distinction this text maintains is between the corporeal (body/flesh) and the incorporeal (soul/spirit). Finally, I will point out that the Gospel of Thomas does not commend the balance of the body and the soul, but rather maintains that the body and the soul are hostile to each other and thus exhorts the reader to despise the former and take care of the latter.

\section{Interpretative Notes on Sayings 29, 87, and 112}

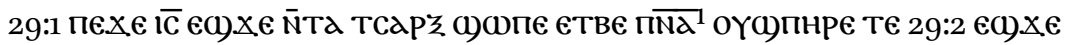

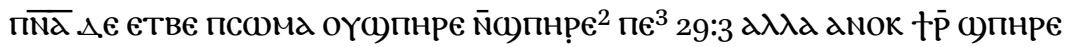

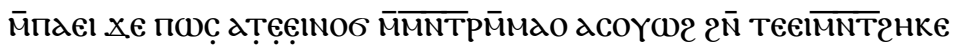

1 For the omission of the definite article $\pi$ - before nouns beginning with $\pi$ in NHC II, see Nagel $1969,399$.

2 The literal meaning of оү()пнрє $\overline{\mathrm{N}}$ )пнрє is "a marvelous marvel," which would correspond to $\theta \alpha \hat{v} \mu \alpha \theta \alpha v \mu \alpha \sigma \tau o ́ v$ in the Greek Vorlage. It is likely, however, that the Vorlage of Gos. Thom. 29:2 
29:1 Jesus said: "If the flesh came into being because of the spirit, it is a wonder. 29:2 But if the spirit (came into being) because of the body, it is a wonder of wonders. 29:3 Yet I marvel at how this great wealth has taken up residence in this poverty."4

Although Gos. Thom. 29:1-2 is sometimes interpreted as an allusion to a creation myth, ${ }^{5}$ I tend to agree with Risto Uro who points out that such an inter-


take this saying at face value, interpreting it as a verbalized thinking process. Jesus is speculating on how the unholy mix of flesh and spirit came into being. If it is on account of the spirit that the flesh came into existence, then the flesh is a wonder; if, on the other hand, the spirit came into existence on account of the flesh, then the spirit is a wonder of wonders. Regardless of what came first and what later, the fact that these two entities are combined with each other is astonishing. It is astonishing, because the spirit is "wealth" and the flesh is "poverty"; in other words, they have nothing in common. In any case, what is important for the following discussion is that the spirit is clearly superior to the body.

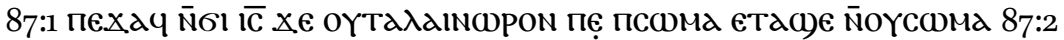

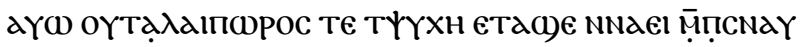

87:1 Jesus said: "Wretched is the body that depends on a body. 87:2 And wretched is the soul that depends on these two."

read $\theta \alpha \hat{v} \mu \alpha$ $\theta \alpha \nu \mu \alpha \dot{\alpha} \omega \nu$, "a marvel of marvels," as in Pseudo-Origen's report on the teaching of the Naassenes $(R e f .5 .8 .18)$. Admittedly, the expression $\theta \alpha \hat{v} \mu \alpha \theta \alpha \nu \mu \alpha \dot{\alpha} \omega \nu$ is not a unique phrase: it also occurs in T. Ab. A7.10 and Galen, Us. part. $15.7(=4.248$ Kühn $=2.365$ Helmreich). Yet the fact that, elsewhere, the Naassenes of Pseudo-Origen make use of sayings 4 (Ref. 5.7.20), 11 (5.8.32), and $33(5.7 .28)$ makes it very likely that $\theta \alpha \hat{v} \mu \alpha \theta \alpha u \mu \alpha \dot{\tau} \omega \nu$ in 5.8.18 is an allusion to Gos. Thom. 29:2.

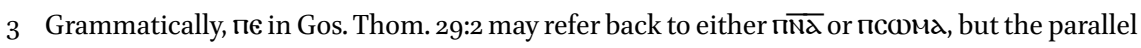
structure of Gos. Thom. 29:1-2 makes it clear that Jesus refers to the spirit: since Te in Gos. Thom. 29:1 refers to тсגрz, пє in Gos. Thom. 29:2 must refer to $\Pi \overline{\mathrm{N} d}$.

4 The Berliner Arbeitskreis puts the closing quotation mark after Gos. Thom. 29:2 and suggests that the "I" of Gos. Thom. 29:3 "belongs to some commentator" (Plisch 2008, 96). I do not find this proposal appealing, since the whole saying makes perfect sense as a coherent argument made by one person.

5 See, e.g., Patterson 2013, 43.

6 Uro 2003,64 . 


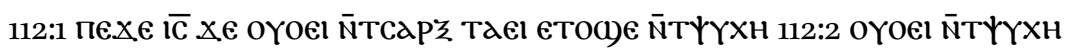

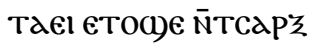

112:1 Jesus said: "Woe to the flesh that depends on the soul. 112:2 Woe to the soul that depends on the flesh."

Sayings 87 and 112 constitute one of the five pairs of doublets in the Gospel of Thomas; they resemble each other lexically, structurally, and conceptually. ${ }^{7}$ On the other hand, there are notable differences between these two sayings. Most remarkably, saying 112 has no parallel for the notion of the body that depends on another body in saying 87 . Scholars have offered several different interpretations for these two "bodies." For instance, according to Uro, ${ }^{8}$ since the world, according to sayings 56 and 8o, ${ }^{9}$ is a body, the body on which the other body depends is the world. As insightful as it is, this interpretation appears to be problematic from a strictly grammatical perspective: in all likelihood, the fact that the indefinite article or precedes the word comd indicates that, in the Greek Vorlage of Gos. Thom. 87:1, the word $\sigma \hat{\omega} \mu \alpha$ was anarthrous. Thus, according to Gos. Thom. 87:1, every single body that depends on another body is wretched.

The principle described in Gos. Thom. 87:1 is, therefore, universal. While it is applicable to an individual body that is dependent upon the world, it is also applicable to the human body, "which depends for sustenance on the devouring of corpses,"10 to the lover who depends on the object of his desire, to the slave who depends on his master, and so on. There can be little doubt that saying 87 is intentionally formulated in such a universalistic and abstract fashion that any of the aforementioned interpretations would do it justice. What is important, however, is that the discussion of the bodies in Gos. Thom. 87:1 lays the groundwork for the description of the misfortunes of the embodied soul in Gos. Thom. 87:2. The ultimate point of saying 87 is the following: every single body that is dependent upon another body is wretched, but the soul that is dependent upon a body, which is itself dependent upon another body is doubly wretched.

It is also worth noting that, while saying 87 contrasts the body with the soul, saying 112 contrasts the soul with the flesh. Although some early Christian texts

\footnotetext{
$7 \quad$ See Ásgeirsson 1997,75 .

8 See Uro $2003,61$.

$9 \quad$ I discuss these two sayings in chapter 2.

$10 \quad$ Davies $1983,76$.
} 
certainly make a distinction between the flesh and the body, ${ }_{1}^{11}$ the fact that sayings 87 and 112 constitute a doublet makes it likely that, in these two sayings, the terms capz and coma are, in fact, synonyms. Moreover, in Gos. Thom. 29:12 (quoted above, pp. 71-72), these two terms also appear to be synonymous. ${ }^{12}$ Thus, it follows that the Gospel of Thomas uses the terms "body" and "flesh" interchangeably.

\section{Tripartite Anthropology in the Gospel of Thomas?}

While saying 29 speaks of the relations between the body/flesh and the spirit, sayings 87 and 112 speak of the relations between the body/flesh and the soul. Moreover, while saying 29 asserts that body/flesh is "poverty" and spirit, "wealth," sayings 87 and 112 do not explicitly state whether the body/flesh or the soul is superior to its counterpart. These facts could indicate that the soul and the spirit play different roles in Thomasine anthropology. In what follows, I would like to demonstrate that this is not the case and that the two terms are, in fact, synonyms.

It is well known that some early Christians acknowledged a difference between the soul and the spirit (see, e.g., 1Cor 2:13-15; 15:46-47; Jude 19). Not everyone in the ancient world was, however, familiar with the distinction: as Richard A. Horsley points out, in Wis 15:11 the terms $\psi v \times \eta^{\prime}$ and $\pi \nu \varepsilon \hat{\nu} \mu \alpha$ are used as synonyms. ${ }^{13}$ Which of the two scenarios are we dealing with in the case of the Gospel of Thomas?

In his seminal article on the impact of Platonism on the Gospel of Thomas, Stephen J. Patterson suggested that the Gospel of Thomas adhered to the tripartite anthropological model outlined in Plutarch's Fac. 943a. According to Plutarch, every human being is a combination of three elements: the body, the soul, and the mind (vovs). It is wrong to think of the mind as a part of the soul: "for in the same degree as soul is superior to body so is mind better and more divine than soul" (trans. H. Cherniss and W.C. Helmbold). According to Patterson, the anthropology of the Gospel of Thomas is identical with the one outlined by Plutarch with only one exception: instead of the term vov̂s, the Gospel of Thomas employs the term $\pi \nu \varepsilon \hat{\mu} \mu \alpha$.

\footnotetext{
11 See, e.g., the discussion of Paul's anthropology in Bultmann 1952-1955, 1:192-203, 232-239.

12 Cf. Uro 2003, 62-63; Plisch 2008, 96.

13 See Horsley 1976, 272.
} 
There is certainly some truth to Patterson's point; as I will try to show in this chapter, it is indeed very likely that Thomasine anthropology is indebted to Middle Platonist anthropology. On the other hand, it seems that Patterson attaches too much importance to the quoted Plutarchan passage. In fact, Plutarch seems to make such a sharp distinction between soul and mind in Fac. 943a, in order to make his anthropology coherent with the eschatological myth he tells shortly after. ${ }^{14}$ It is not the only instance where Plutarch acts as the occasion demands: when telling another eschatological myth (Gen. Socr. $591 \mathrm{~d}-\mathrm{e})$, he modifies his anthropology by saying that vov̂s, being a $\delta \alpha i \mu \omega \nu$, exists outside the human being. As Werner Deuse has recently pointed out, there is no "uniform conception" of mind-soul relations in Plutarch's writings. In order to understand why Plutarch chose this particular anthropological model, one should ascertain what the intention of the text in question is. ${ }^{15}$ Remarkably, in Virt. mor. 441d-442a, where Plutarch does not hide behind the mask of a fictional character, ${ }^{16}$ he follows Plato in speaking about two parts of the soul, the rational and the irrational.

It is evident that the view outlined in Plutarch's Fac. 943a should not be seen as a communis opinio ${ }^{17}$ in fact, vovิ and $\psi v \times \eta \dot{~ w e r e ~ s o m e t i m e s ~ u s e d ~ a s ~ m e r e ~ s y n-~}$ onyms. As Horsley points out, this is the case with Wis 9:15. ${ }^{18}$ The same holds true for the Corpus Hermeticum. According to Horsley, Poimandres does not "maintain any anthropological distinction" between vov to him, vovิ and $\psi v x \eta$ ' "stand more in a parallel relationship than in a superiorinferior one."19 See especially Corp. Herm. 1.17:

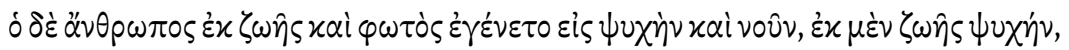
$\dot{\varepsilon} x \delta \dot{\varepsilon} \varphi \omega \tau \dot{\varphi} \varsigma$ v०ûv.

\footnotetext{
14 See Deuse 2010, $185^{-186 .}$

15 See Deuse 2010, 186.

16 The narrator of the myth in De facie in orbe lunae is Sulla; the narrator of the myth in De genio Socratis is Simmias.

17 This is not to say that this passage in Plutarch is unparalleled in ancient Platonism. See the discussion of Philo, Mos. 2.288, in chapter 4 (pp. 107-109).

18 Horsley 1976, 272: "In 9:15 $\psi v \chi \eta \dot{~ a n d ~} \pi v \varepsilon \hat{v} \mu \alpha$ [sic] are parallel, synonymous terms for the soul which the corruptible, earthly body weighs down." Horsley's $\pi \nu \varepsilon \hat{\mu} \mu \alpha$ is clearly a misprint for voûs.

19 Horsley 1976, 270. It is worth noting, however, that Horsley mistakenly states that in Poimandres vovิৎ and $\pi v \varepsilon \hat{\mu} \alpha$ are synonyms. In reality, the Hermetic $\pi \nu \varepsilon \hat{\nu} \mu \alpha$ is, as C.H. Dodd puts it, "one of the higher material elements, along with fire and air." See Dodd 1953, 216.
} 
From life and light the man became soul and mind; from life came soul, from light came mind. ${ }^{20}$

According to Corp. Herm. 1.21, one can obtain salvation only by learning that


("god and father"), is light and life. ${ }^{21}$ Since soul and mind originate from life and light, and since life and light are clearly not subordinate to each other, Horsley's observation is most certainly correct.

Another problem with Patterson's interpretation is that, according to him, the Gospel of Thomas adheres to the Platonist tripartite anthropological model as described by Plutarch, even though the term vov̂s is never employed in the Gospel of Thomas, which, instead of vov̂s, speaks of $\pi \nu \varepsilon \hat{u} \mu \alpha$. Patterson argues that this latter term is "a middle Platonic synonym for vov̂.". 22 There is, however, only one ancient author who sometimes appears to use the term $\pi v \varepsilon \hat{\nu} \mu \alpha$ as an equivalent for the term voûs: Philo. The reason why Philo employed the term in such a way is, according to Patterson, the Platonist exegesis of the biblical account of the creation of humankind; thus, God's "breath" (Gen 2:7 LXX: $\pi \nu \circ \eta$ ) was understood as $\pi \nu \varepsilon \hat{v} \mu \alpha$, and $\pi \nu \varepsilon \hat{v} \mu \alpha$ as $\nu \circ \hat{\varsigma} \varsigma^{23}$

Patterson's hypothesis appears to be quite similar to the claim Birger Pearson made in 1973. According to Pearson, Hellenistic Jews preferred to use the

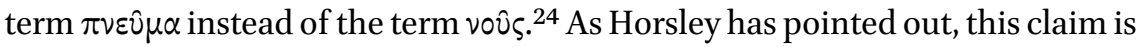
unsubstantiated. ${ }^{25}$ The same holds true for Patterson's train of thought. First, it is clear that some Jews distinguished between $\pi v \varepsilon \hat{\mu} \mu \alpha$ and vovิธ-e.g., Paul (see 1Cor 14:14). Some early Christians were also aware of this distinction-e.g., the author of the Gospel of Mary (BG 10.2O-23). Second, as I will demonstrate, Philo's exegesis of Gen 2:7 does not bear witness to any tradition that might have credited the Thomasine $\pi v \varepsilon \hat{\mu} \alpha$ with its alleged Platonist meaning.

Let us consider Det. 80-84. In this passage, Philo deals with an exegetical problem: his goal is to make away the discrepancies between the $\psi v \times \dot{\eta} \zeta \hat{\omega} \sigma \alpha$ of

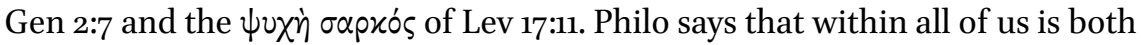
an animal and a human being and that there are two respective powers in each

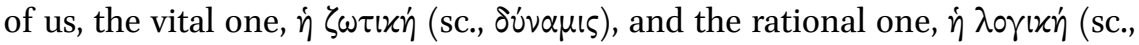

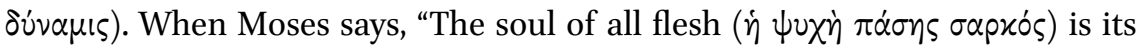

\footnotetext{
$20 \quad$ Corp. Herm. 1.17, trans. B.P. Copenhaver.

21 Cf. Pearson 1973, 8.

22 Patterson 2013, 42.

23 Ibid., 40-41.

24 Pearson 1973, 11.

25 See Horsley 1976, 271.
} 
blood" (Lev 17:11), he refers to the vital force. When he says that God breathed

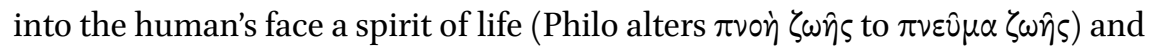
"the human ( $\delta \alpha \nu \theta \rho \omega \pi \circ)$ became a living soul" (Gen 2:7), he refers to the rational force. Thus, according to Moses, there are two souls: blood is the carnal soul

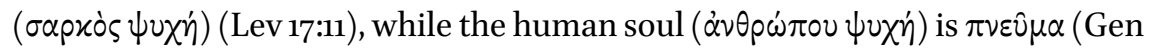
2:7). The latter, according to Philo, is the superior form of the soul ( $\tau \dot{0} \tau \hat{\eta} \varsigma \psi v \chi \hat{\eta} \varsigma$

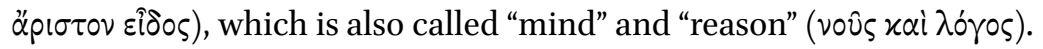

At first glance, one might think that, in this passage, Philo uses $\pi v \varepsilon \hat{\mu} \mu \alpha$ and vov̂ as synonyms. However, in order to understand Philo, we must distinguish his explanatio from the biblical explanandum (i.e., that which needs to be explained). As Sami Yli-Karjanmaa points out, in all instances that Philo uses $\pi v \varepsilon \hat{\mu} \alpha$ in a "spiritual" sense (i.e., not as a "breath" or "wind"), it is always as a biblical lemma (= explanandum), rather than a bona fide Philonic term. ${ }^{26}$ Thus, $\pi v \varepsilon \hat{u} \mu \alpha$ makes an appearance in Det. $80-84$ only because it is part of the biblical lemma in question. ${ }^{27}$ It is then "translated" by means of the Platonist categories of "mind," "reason," and "soul." To consider "spirit" to be Philo's synonym for "mind" would, therefore, be to misunderstand his biblical exegesis.

It follows that the identification of vov̂ with $\pi \nu \varepsilon \hat{u} \mu \alpha$ was likely not a widespread Middle Platonist notion that could have made its way into the Gospel of Thomas. Although one might argue that Det. 8o-84 and similar Philonic passages could have inspired some less insightful readers to use $\pi \nu \varepsilon \hat{\nu} \mu \alpha$ as a synonym for vovิs, it does not seem justified to consider them as a background for the Thomasine use of $\pi v \varepsilon \hat{\nu} \mu \alpha$, since there are no indications of a Philonic influence on the Gospel of Thomas. Therefore, it is unlikely that $\pi v \varepsilon \hat{\nu} \mu \alpha$ in the Gospel of Thomas is used to designate the Middle Platonist notion of vov̂s.

Admittedly, while it is not identical with the Middle Platonist vovs, the Thomasine $\pi v \varepsilon \hat{\nu} \mu \alpha$ might also not be identical with $\psi v \times \eta$. It is worth noting, however, that there is nothing in the Gospel of Thomas that would imply that $\psi v \times \eta \dot{~ a n d ~} \pi \nu \varepsilon \hat{\mu} \mu \alpha$ are not synonyms. As I have already pointed out, these two terms are synonymous in Wis 15:11. The same may be the case with the Gospel of Thomas. It seems that at least one Thomasine saying supports this claim.

In Gos. Thom. 114:2, Jesus tells his male disciples that he will make Mary as


I have argued elsewhere, ${ }^{28}$ it is likely that the Thomasine notion of a "living

\footnotetext{
26 Yli-Karjanmaa 2016, 281-282.

27 Although the biblical text of Gen 2:7 speaks about $\pi v \eta^{\prime}$, not $\pi v \varepsilon \hat{\mu} \alpha$, it seems clear that, according to Philo, $\pi v \varepsilon \hat{\nu} \mu \alpha$ is what Moses meant. See the discussion of Gos. Thom. 114:2 below (pp. 77-78).

28 See Miroshnikov 2017.
} 
spirit" is inspired by the creation narrative of Gen 2:7,29 thus, what is meant by becoming a "living spirit" is the attainment of the condition of Adam, as he, too, had become a "living soul" $(\psi v \chi \grave{\eta} \zeta \hat{\omega} \sigma \alpha)$.

Admittedly, the word $\pi v \varepsilon v \hat{\mu} \alpha$ does not occur in Gen 2:7. However, the Biblical text does employ a cognate to $\pi v \varepsilon \hat{v} \mu \alpha$ - viz., $\pi \nu \circ \eta_{-}$-and at least some ancient readers of Gen 2:7 certainly thought that the text spoke about $\pi v \varepsilon v \hat{\mu} \alpha$. For instance, in Det. 8o — as I have noted above (p. 77) —and Leg. 3.161, Philo quotes

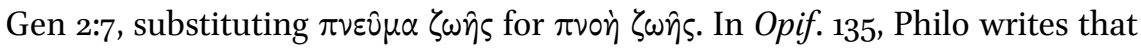
what God breathed into the human was nothing other than a "divine spirit,"


be a more appropriate (biblical) category than $\pi \nu$ n. $^{30}{ }^{30}$ This suggestion receives support from Wis 15:11, a passage that clearly alludes to Gen 2:7, in which the

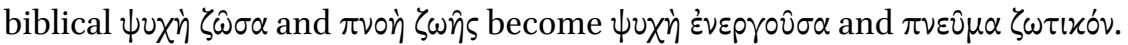

Since the notion of a "living spirit" draws upon Gen 2:7, where God makes Adam a "living soul," it seems reasonable to surmise that, saying 114 in particular and the Gospel of Thomas in general does not seem to distinguish between $\psi v \chi \eta$ and $\pi v \varepsilon \hat{\mu} \mu \alpha$. Thus, my conclusion is that not only is the term $\pi v \varepsilon \hat{\nu} \mu \alpha$ in the Gospel of Thomas not equivalent to the Middle Platonist term vov̂, but also that it is in fact likely that the anthropology of the Gospel of Thomas is not tripartite (flesh/body vs. soul vs. spirit), but bipartite (flesh/body vs. soul/spirit).

\section{The Body vs. the Soul}

The next question I need to address is what the Gospel of Thomas says about the relationship between the body and the soul. I would like to focus on the interpretation of the nature of the soul in saying 112. Quite notably, two prominent scholars of the Gospel of Thomas, Uro and Patterson, have recently offered a reading of the saying against the background of Tim. $87 \mathrm{c}-89 \mathrm{a}$. The line of argument goes as follows.

According to Timaeus, the main dramatis persona of the dialogue, the living being ( $\tau \dot{\partial} \zeta \hat{\omega} \circ v$ ), is the combination ( $\tau \dot{0} \sigma \nu v \alpha \mu \varphi \sigma^{\prime} \tau \varepsilon p \circ v$ ) of the body and the soul.

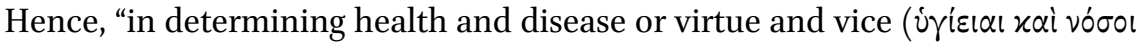

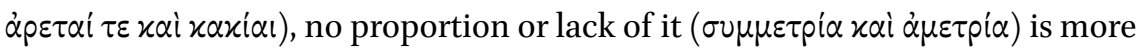
important than that between soul and body" (87d; trans. D.J. Zeyl). If the soul

29 Cf. Perkins 1995, 558-56o; DeConick 1996, 19-2o; Kvalbein 20o6, 214.

30 Yli-Karjanmaa 2016, 28o-281. 
is strong and excellent, but the body that carries it about is too weak, then the living being as a whole is not beautiful (oi xa $x$ ov $^{2}$ ). If the proportion is disturbed in the opposite way, the outcome is equally unfortunate. If, however, the body and the soul are a match, then the living being is "the most beautiful and the

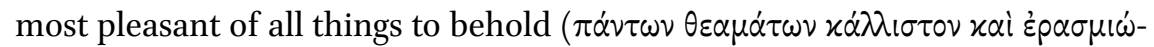
$\tau \alpha \tau o v)$." Timaeus then goes on to provide examples of the mismatch between body and soul:

When within it (i.e. the living being) there is a soul more powerful than the body and this soul gets excited, it churns the whole being and fills it from inside with diseases, and when it concentrates on one or another course of study or inquiry, it wears the body out. And again, when the soul engages in public or private teaching sessions or verbal battles, the disputes and contentions that then occur cause the soul to fire the body up and rock it back and forth, so inducing discharges which trick most socalled doctors into making misguided diagnoses. But when, on the other hand, a large body, too much for its soul, is joined with a puny and feeble mind, then, given that human beings have two sets of natural desiresdesires of the body for food and desires of the most divine part of us for wisdom - the motions of the stronger part will predominate, and amplify their own interest. They render the functions of the soul dull, stupid and forgetful, thereby bringing on the gravest disease of all: ignorance. ${ }^{31}$

In order to avoid this unhappy quarrel, the body and the soul should be "in equipoise" (iroppó $\pi \omega$ ). We should neither exercise our souls without also exer-

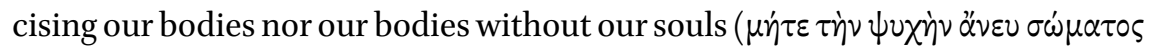

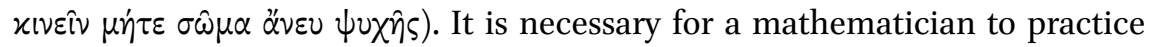

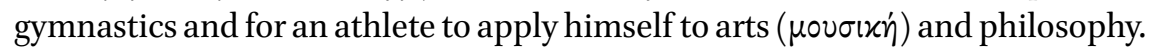
As A.E. Taylor pointed out, Timaeus lays out the Pythagorean theory that health is irovorin, the balance between the body and the soul. ${ }^{32}$ It is also worth noting that this passage in Timaeus made an impact on some Middle Platonists. The importance of maintaining body and soul in equilibrium was later repeated by Plutarch (see, e.g., Tu. san. 135e-f; Quaest. conv. 681d-f; Cons. ux. 610a-b) and Apuleius (Plat. Dogm. 216-218).

Although Uro and Patterson both interpret saying 112 against the background of Tim. $87 \mathrm{c}-89 \mathrm{a}$, their interpretations are significantly different. Patter-

$31 \quad$ Tim. $87 \mathrm{e}-88 \mathrm{~b}$, trans. D.J. Zeyl.

32 See Taylor 1928, 623 . 
son ascribes to the Gospel of Thomas the tripartite anthropology of the mortal body, the mortal soul, and the divine and immortal spirit (see above) and argues that the focus of saying 112 "is on the difficult relationship that exists between the body and the soul." While the soul is not superior to the body, they are both inferior to the mind. They always struggle with each other, and what Plato described as the lack of balance between the body and the soul is, in fact, "the essence of mortal existence." 33

Even leaving aside Patterson's questionable suggestion that the Thomasine anthropology is tripartite, his interpretation of saying 112 still remains problematic. The Gospel of Thomas does not hold that the body and the soul are equally abominable; while the body is malicious (see chapter 2), nothing indicates that there is something wrong with the soul. That the attitude of the Gospel of Thomas towards the soul is positive is clear from the wording of sayings 25 and 28 .

In Gos. Thom. 28:3, Jesus says that his soul became afflicted for the sons of

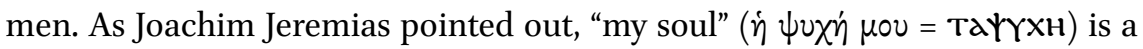
Semiticism that also occurs in Mark 14:34 ( $\pi \varepsilon p i \lambda v \pi o ́ \varsigma ~ \varepsilon ̇ \sigma \tau \nu \dot{\eta} \psi v x \dot{\eta} \mu \circ v$, "my soul is deeply grieved") and John 12:27 ( $\dot{\eta} \psi v \times \dot{\eta}^{\prime} \mu \circ v \tau \varepsilon \tau \dot{\alpha} \rho \alpha \kappa \tau \alpha \mathrm{l}$, "my soul is troubled"). In all these instances, "my soul" is identical with "I." ${ }^{34}$ It is unlikely that the Thomasine Jesus would use this expression to refer to himself, if the Thomasine term "soul" designated the mortal element within as distinct from the divine and immortal element.

In Gos. Thom. 25:1, Jesus says, "love your brother like your soul," мєрє пексоN $\bar{N} \Theta \epsilon \overline{\mathrm{N}} \mathrm{TEK} Y \mathrm{XH}$. Gos. Thom. $25: 1$ is a version of the love commandment from Lev


as yourself") that achieved wide circulation among early Christians. It is worth noting that some texts (e.g., Mark 12:31) present this commandment the same way as phrased in Lev 19:18 LXX, while others (e.g., Barn. 19:5), like the Gospel of Thomas, counsel the love of one's soul rather than of oneself. Quite remarkably, the Didache includes both variants and exhorts the reader to love others

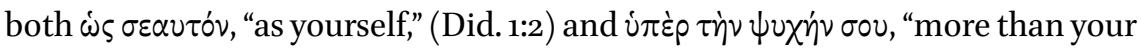
soul" (Did. 2:7). There can be no doubt that these two expressions, used in the different versions of the love commandment, "your soul" and "yourself," are synonymous. ${ }^{35}$ It is unlikely that, in Gos. Thom. 25:1, the Thomasine Jesus would

33 Patterson 2013, 41-42.

34 See Jeremias 1958, 71. This Semitism first appears in the Septuagint (see, e.g., Ps 41/42:7,

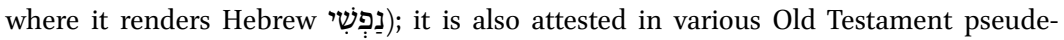
pigrapha (see Bertram et al. 1974, 9:633). 
say "as your soul" instead of "as yourself," if the soul were among the inferior elements of the human compound.

In sum, a careful reading of sayings 25 and 28 demonstrates that the Gospel of Thomas by no means treats the body and the soul as equals. Jesus refers to himself as "my soul" in Gos. Thom. 28:3, and he means "yourself" when he says "your soul" in Gos. Thom. 25:1. The phraseology of these sayings makes it clear that, in the Gospel of Thomas, the word "soul" designates one's own "self" or one's own "person." The Thomasine Jesus would not phrase these sayings the way they are, unless he considered the human being to be nothing other than the soul itself.

Jesus' attitude towards the body is drastically different; in saying 28 , before he identifies himself with his soul (Gos. Thom. 28:3), he says that he merely "appeared" in the flesh (Gos. Thom. 28:1), implying that being in the flesh is incidental to his existence and unrelated to his true self. This unflattering portrayal of the body becomes even more evident when we turn to the other Thomasine sayings: the body is "poverty" (saying 29) and has no worth unless the soul inhabits it (cf. my discussion of sayings in 56 and 80 in chapter 2).

Uro's reading of saying 112 is different from that of Patterson. He points out that the Gospel of Thomas is aware of different ways of characterizing "the immortal or divine part of the human being," including but not limited to the "spirit," the "soul," the inner "kingdom" (Gos. Thom. 3:3), and the inner "light" (Gos. Thom. 24:3). ${ }^{36}$ Thus, unlike Patterson, Uro does not assume that Thomasine anthropology presupposes fundamental differences between the soul and the spirit, but rather sees these two entities as identical. Uro furthermore argues that saying 112 expresses ideas that fundamentally agree with what Plato says about the body-soul relationship in his Timaeus: ${ }^{37}$

[Gos. Thom. 112:1] reveals a concern about the body. The body, too, can become unhappy if it depends upon the soul. Although Thomas does not say it, the logical implication is that the reverse can also be true. The body can be happy and healthy if no unhealthy relationship between body and soul exists. ${ }^{38}$

\footnotetext{
$36 \quad$ Uro 2003, 64.

37 Admittedly, Uro's primary focus here is on Plutarch, as he was roughly contemporary with the production of the Gospel of Thomas; it is worth noting, however, that, as I have already pointed out, in his observations on the body-soul relationship Plutarch merely follows in the footsteps of Plato's Timaeus.

$38 \quad$ Uro 2003,59 .
} 
The saying, then, is not "an exhortation to neglect the body completely or to regard the body and soul as being hostile to each other." ${ }^{39}$ As fascinating as this interpretation is, I do not think it does justice to the intellectual outlook advocated by the Gospel of Thomas. Saying 112 does not necessarily imply that the body and the soul should be in equipoise. The saying deals with the relationship between the embodied soul and the ensouled body. According to Gos. Thom. 112:1, the flesh/body that depends on the soul is wretched; according to Gos. Thom. 112:2, the soul that depends on the flesh/body is also wretched. Significantly, the third option, a harmonious coexistence of these two, is never mentioned. Nothing indicates that it is even on the table.

As I have already pointed out, sayings 87 and 112 constitute a doublet. The second halves of these two sayings (Gos. Thom. 87:2 and 112:2) are nearly identical and most certainly constitute the focal point of either of them: the soul that depends on the body is wretched-i.e., the soul should not depend on the body. Unlike their second halves, the first halves of these sayings are different: Gos. Thom. 87:1 discusses the body that depends on another body; Gos. Thom. 112:1 discusses the body that depends on the soul.

It is unlikely that either Gos. Thom. 87:1 or Gos. Thom. 112:1 have any significance in isolation from their respective counterparts. Rather, Gos. Thom. 87:1 and 112:1 pave the way for Gos. Thom. 87:2 and 112:2. It is the second halves of these two sayings that deliver the main message of the respective sayings overall: the soul should be independent from the body. It does not seem likely that Gos. Thom. 87:1 reveals a concern for those bodies that depend on other bodies; rather, the purpose of Gos. Thom. 87:1 is to place emphasis on Gos. Thom. 87:2 (even bodies suffer when they depend on other bodies; imagine what it is like for souls!). Similarly, Gos. Thom. 112:1 does not reveal any concern for the body that depends on the soul, but rather depicts an alternative to the situation described in Gos. Thom. 112:2. Thus, saying 112 contrasts the human dominated by the soul with the human dominated by the body, urging its reader to choose between two mutually exclusive options: either you subordinate your body to your soul, to the detriment of the body (Gos. Thom. 112:1), or you subordinate your soul to your body, to the detriment of the soul (Gos. Thom. 112:2).

Moreover, other Thomasine sayings hardly provide any support for the claim that the Gospel of Thomas is concerned with bodily wellbeing. Thomasine views on the body are by no means favorable. As I have pointed out in the previous chapter, the Gospel of Thomas maintains that bodies are corpses, as worthless and lifeless as stones and logs. Moreover, according to Gos. Thom. 
29:3, the spirit/soul is "great wealth" and the body is "poverty," and it is thus astonishing that the former should have taken up residence in the latter. It is clear, therefore, that the two entities in question, the body and the soul, are not of equal value. The Gospel of Thomas praises the soul and defames the body. The soul's wellbeing is important; the body's is not.

It follows, therefore, that, according to the Gospel of Thomas, the body and the soul are mortal enemies: they are in constant struggle and, whenever one of them prevails, the other necessarily suffers. Surely, there can be no doubt on whose side the Gospel of Thomas is: of the two alternatives presented in saying 112 (viz., the dominance of the body at the expense of the soul and the dominance of the soul at the expense of the body), the reader is supposed to choose the latter option.

Thus, it is unlikely that saying 112 should be read against the background of Tim. $87 \mathrm{c}-8 \mathrm{ga}$. The fact that Platonists sometimes commended the balance of the body and the soul does not seem to have any bearing on the understanding of the Gospel of Thomas. With regard to the dialogues of Plato, the closest parallel to the sentiment expressed in sayings 29,87 , and 112 comes from Phaedo.

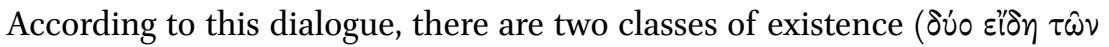
ov $v \tau \omega v)$ : the one that is invisible and always remains the same and the one that is visible and always changes (79a). The soul is more like the invisible existence than the body, whereas the body is more like the visible existence than the soul (79b). Clearly, then, the difference between the soul and the body is fundamental; as Plato's Socrates puts it, "the soul is most like the divine, deathless, intelligible, uniform, indissoluble, always the same as itself, whereas the body is most like that which is human, mortal, multiform, unintelligible, soluble and never consistently the same" (Phaed. 8ob; trans. G.M.A. Grube).

The body ought to be subjected to the soul: "Whenever the soul and the body are together, nature ordains the latter to be slave and to be ruled and the former



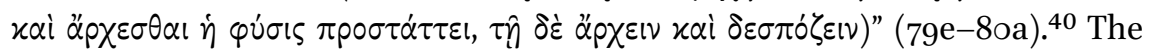
soul exercises its power by mastering the affections of the body ( $\tau \dot{\alpha} x \alpha \tau \dot{\alpha} \tau \dot{0}$ $\sigma \hat{\omega} \mu \alpha \pi \dot{\alpha} \theta \eta)$ and opposing them-e.g., by not letting the body drink when it

40 Cf. Tim. 34c, where the demiurge makes the world's soul "to be the body's mistress and to rule over it as her subject" (trans. D.J. Zeyl). Cf. also Aristotle's Protrepticus: "Further, part of us is soul, part body; the one rules, the other is ruled; the one uses, the other is present as its instrument" (fr. 6 Ross = fr. B 59 Düring = Iamblichus, Protr. 7 ; trans. J. Barnes and G. Lawrence). In Hutchinson and Johnson 2005, 244-251, this fragment was proven to belong to Aristotle; cf. Jaeger 1948, 65-66. 
is thirsty and eat when it is hungry (94b-e). It is worth noting, however, that Plato's "nature" is a normative concept. As David Gallop points out, "the soul's 'natural' fitness to rule the body does not mean that it always does so, just as in Respublica (430e-431a) the 'natural' superiority of reason does not mean that it is actually in control."41

Thus, while the soul ought to rule over the body, the unsavory truth is that we are slaves to our own bodies (66b-d) and that the body acts as both the chains $(67 \mathrm{~d})$ and the prison (82e) of the soul. The body is a hindrance to the soul's philosophical quest, and the soul of a true philosopher "most disdains the body, flees from it and seeks to be by itself" (65d; trans. G.M.A. Grube). We will never fully possess the truth "as long as we have a body and our soul is con-

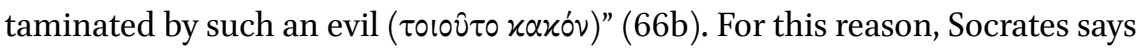
that $\tau \dot{0} \mu \varepsilon \lambda \varepsilon^{\prime} \tau \eta \mu \alpha \tau \hat{\omega} \nu \varphi(\lambda \circ \sigma o ́ \varphi \omega \nu$, "what philosophers practice doing," is $\lambda \dot{v} \sigma \varsigma \varsigma$

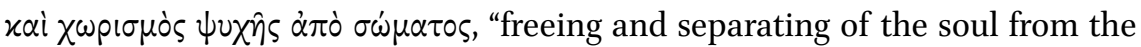
body"-i.e., death $(67 \mathrm{~d}) .{ }^{42}$

Similar sentiments often occur in writers of Platonist persuasion of the historical period roughly contemporary with the composition of the Gospel of Thomas. I will discuss one author, Maximus of Tyre, as an example. It is worth noting that, as M.B. Trapp points out, Maximus was not "a declared and partisan Platonist" - even though the principal manuscript of his Dissertationes, Parisinus Graecus 1962, calls Maximus a "Platonic philosopher," $\Pi \lambda \alpha \tau \omega \nu$ ixòs

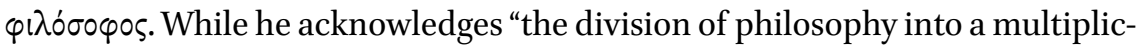
ity of competing sects," ${ }^{43}$ he never approves of it. Moreover, Maximus was by no means "a school philosopher offering a systematic course of instruction in philosophical doctrine." ${ }^{44}$ On the other hand, it is clear that the philosophical component of Dissertationes "is in practice consistently Platonizing, whatever the explicit account of philosophy and his own orientation within it Maximus may give." 45

41 Gallop 1975, 141.

42 Cf. the opening paragraph of Alcinous' handbook, where he defines philosophy as $\lambda \dot{\sigma} \sigma \varsigma$

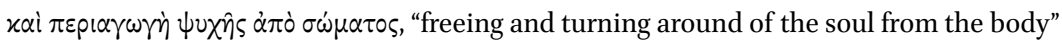
(Didasc. 1.1; trans. J.M. Dillon). Dillon 1993a, 52, points out that this definition is a combination of Phaed. 67d and Resp. 521c, where Socrates speaks of "turning a soul ( $\pi \varepsilon p 1 \alpha-$


C.D.C. Reeve).

45 Ibid., xxvii. 
In what follows, I summarize the notions on the body-soul relationship that Maximus expresses in Diss. 7 , an oration where Maximus draws on the imagery of Plato's dialogues to convince his audience of the superiority of the soul over the body ${ }^{46}$ The manuscript title of this oration is "Which Illnesses Are the More Harsh, Those of the Body or Those of the Soul" (trans. M.B. Trapp).

The human being ( $\dot{\alpha} \dot{\alpha} v \theta \omega \pi \circ \varsigma)$ is a compound of the body and the soul. These two components are not equal (Diss. 7.1). The latter rules over the former


like their ruler. "The people are a creature swift to anger, vehement in its desires, dissipated in its pleasures, spineless in grief, and harsh in its rages $(\chi \rho \eta \mu \alpha ~ o \xi \dot{\nu}$

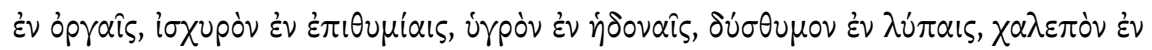
$\theta u \mu o i \varsigma)$, exactly like the passions of the body, which is itself desirous ( $(\dot{\pi} \pi \theta u \mu \eta-$

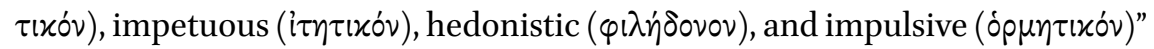
(trans. M.B. Trapp). The ruler, on the other hand, is by nature the strongest, most authoritative, honorable, prudent, and rational element in a state, just as the soul is in the human being. Hence, "the soul is more valuable than the body" (Diss. 7.2; trans. M.B. Trapp, slightly altered).

Later on, Maximus argues that the noble soul even welcomes the dissolution

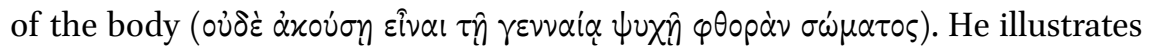
his point in the following passage, where he combines Plato's notion of the body as the soul's prison, Plato's notion of the body as the soul's tomb (Crat. 40oc; Gorg. 493a; Phaedr. 25oc), ${ }^{47}$ and the imagery of Plato's allegory of the cave (Resp. 514a-517a):

You might compare the case of a prisoner who can see the wall of his prison ( $\delta \varepsilon \sigma \mu \omega \tau$ inp

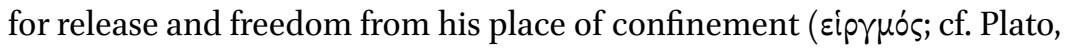
Phaed. 82e), so that he can step from the deep and murky dark in which

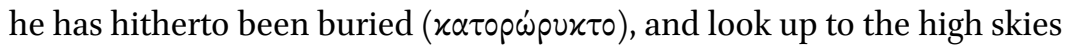
and glut himself on the bright light of day. ${ }^{48}$

Skin, bones, and flesh are nothing else but "short-lived mantles and flimsy and tattered rags" of the soul. Thus, the good soul ( $\dot{\eta} \dot{\alpha} \gamma \alpha \theta \dot{\eta} \psi v \times \dot{\eta})$ has no care ( $\dot{\alpha} \mu \lambda \lambda \varepsilon \hat{\imath})$

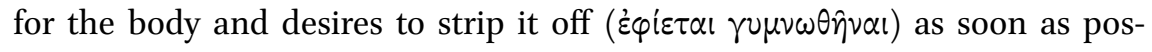



\footnotetext{
46 Cf. ibid., 59 .

47 I discuss these Platonic passages in chapter 2 (pp. 50-54).

48 Diss. 7.5, trans. M.B. Trapp.
} 
into the body like a sluggish creature in its burrow loves $(\varphi(\lambda \varepsilon \hat{\imath})$ that burrow and wishes never to be parted from it or to have to crawl out of it" (trans. M.B. Trapp). This love for the body will make the soul suffer until it comes to realize that "death is indeed a healer that will free you from misfortune and from an insatiable, disease-ridden beast [i.e., from the body]" (Diss. 7.5; trans. M.B. Trapp).

The ideological affinities between the Platonist notions of the body-soul relationship and sayings 29, 87, and 112 are evident. According to the Gospel of Thomas, the human being has two components, the body (occasionally called "the flesh") and the soul (occasionally called "the spirit"). To describe the relationship between these two components, the Gospel of Thomas uses the term "dependence." Either the soul depends on the body, or the body depends on the soul. In other words, either the soul dominates and the body obeys, or vice versa; there is no third option. In both cases, the component brought into subjection is "wretched." As long as the human being lives, the embodied soul and the ensouled body are engaged in a constant struggle for dominance. The outcome of this struggle is a matter of utmost importance, since the body and the soul are by no means of equal worth: whereas the body is "poverty," the soul is "great wealth," and it eludes Jesus' understanding how the latter has taken up residence in the former. Thus, in the struggle between the soul and the body, the Gospel of Thomas clearly vouches for the soul, meaning that the reader of the Gospel of Thomas ought to nurture the soul, disdain the body, and by no means allow the soul to become subjected to the body.

Thomasine anthropology thus makes great sense in light of the Platonist body-soul dualism. Plato and later Platonists maintained that the two components of the human being are in all respects different, and that the soul is undeniably better than the body. The passions are the body's allies and together they go to great lengths to prevent the soul from contemplating the divine realm. The soul's mission is thus to rule over and discipline the body, but the grim reality of human life is that instead of being in control, the soul remains the body's slave. For this reason, we should neither regret nor resist the death of the body. While the ignorant soul inevitably feels attached to the body, the wise soul longs to escape its imprisonment from the body, to liberate itself


$7 \cdot 4)$.

It is worth noting that such comparison with the Platonist notions of the body-soul relationship makes better sense of the reasoning behind the "anthropological" sayings of the Gospel of Thomas. For instance, while the Thomasine Jesus never explains why the body that depends on the soul is wretched, it is likely that the body's misery is rooted in its inability to pursue its urges. It is also 
likely that these sayings presuppose a positive evaluation of physical death. In the end, only the death of the body can terminate the soul's captivity. Thus, it is possible that, when he says that the soul that depends on the body is wretched, the Thomasine Jesus envisions death as the soul's ultimate escape from its misery, since only after the dissolution of the body will the soul achieve complete independence.

It seems plausible, therefore, that the author(s) of sayings 29,87 , and 112 had Platonist inclinations and that these sayings should be understood against a Platonist background. This thesis receives additional support from the fact that the Thomasine understanding of the body expressed in sayings 56 and 80 is, as I have argued in chapter 2, both indebted to and in dialogue with the Platonist tradition. Finally, it should be noted that the very dualism of Thomasine anthropology - i.e., the division of the human being into two opposing parts, a corporeal and an incorporeal one, identified as the body and the soul—also appears to be a Platonizing tendency.

According to Jackson P. Hershbell, "it is difficult to find any clear emphasis on the $\sigma \hat{\omega} \mu \alpha-\psi v \times \eta^{\prime}$ division" in the early Christian literature before the apologists. ${ }^{49}$ It is not until the time of the apologists that Hershbell is able to single out Diogn. 6 as a text with a "clearly formulated division of man into body and soul." ${ }^{50}$ This passage elaborates upon the analogy of the relationship between the soul $\left(\psi v \times \eta^{\prime}\right)$ and the body/flesh $(\sigma \omega \hat{\mu \alpha / \sigma \alpha} \rho \xi)$ and that between the Christians and the world. According to this passage, the body is a "mortal dwelling

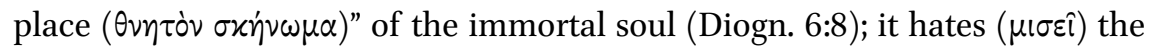
soul and is at war ( $\pi \circ \lambda \varepsilon \mu \varepsilon \hat{)})$ with it (Diogn. 6:5); the soul "is not of the body"

49 Admittedly, there are several exceptions-e.g., Matt 10:28, where Jesus contrasts persecutors, who can kill the body but not the soul, with God, who can destroy both the body and the soul in Gehenna. This verse presupposes that the body and the soul are distinct and separable (cf. Gundry 1976, 115; pace Schweizer 1976, 247-248, who argues that, here, as in Matt 6:25, the terms $\psi v \times \eta \dot{~ a n d ~} \sigma \omega \hat{\omega} \mu \alpha$ "designate man as a whole, but under different aspects"). Yet the Matthean Jesus does not contrast the body with the soul, but rather physical death with eternal punishment after the resurrection and the judgement. His point is not that the sufferings of the soul are worse than the sufferings of the body, but that the destruction of the whole person, the reunited body and soul, is far more serious than the destruction of the body alone. The embodiment of the soul is thus a prerequisite for eternal damnation. As Milikowsky 1988, 242, points out, in Matthew, "Gehenna is the place of retribution for the reunited body and soul; the soul by itself has no real existence and does not receive retribution." Thus, the Matthean anthropology is dualistic, but only to some extent: while the soul can survive the dissolution of the body, it does not seem to be alive in the truest sense of the word, until it reunites with the resurrected body. 


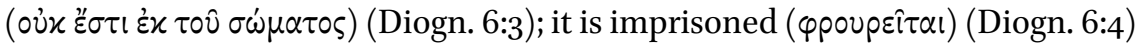
in and confined ( $\dot{\gamma} \gamma \mathcal{\varepsilon} x \lambda \varepsilon \varepsilon \sigma \tau \alpha$ ) (Diogn. 6:7) within the body.

With respect to the present discussion, it is especially remarkable that, as Clayton N. Jefford has pointed out, "this vibrant image draws on various middlePlatonic considerations of reality." 51 Already in the nineteenth century, Johann Karl Theodor Otto noted that the phrase "Christians are detained in the world

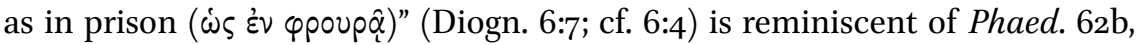
where Socrates says that we are all "in a sort of prison ( $\left.\varepsilon^{\prime} \nu \tau \iota \nu \iota \varphi \rho o v \rho \hat{\alpha}\right) . "{ }^{\prime 2}$ Henry G. Meecham pointed out that the claim that Christians are not allowed to abandon the position ( $\tau \dot{\alpha} \xi ı)$ ) to which God ( $\delta \theta \varepsilon o ́ \varsigma)$ has appointed them reflects Apol. 28e-29a (cf. Phaed. 62b), where Socrates refuses to desert the post ( $\tau \dot{\alpha} \xi ı)$ to which "god (o $\theta \varepsilon o ́ s)$ " (i.e., Apollo) has ordained him. ${ }^{53}$ Finally, Jefford has recently argued that the anthropology of Diogn. 6 ultimately derives from Phaedr. 245c-25oc. ${ }^{54}$

Of all early Christian texts, Diogn. 6, with its portrayal of the opposition of the body to the soul, appears to offer the closest parallel to the Thomasine bodysoul dualism. Diogn. 6 is also the most striking instance of the indebtedness of the author of Diognetus to the Platonist tradition. ${ }^{55}$ It can hardly be a coincidence, and it seems likely that the Gospel of Thomas with its body-soul dualism also found its inspiration in Platonism.

Moreover, it seems that Thomasine anthropology is in a way more faithful to the Platonist understanding of the body-soul relationship than that of Diogn.

$5^{1} \quad$ Jefford 2013, 64 .

52 Otto $1879,182$.

53 See Meecham 1949, 117.

54 See Jefford 2013, 224-225.

55 Another early Christian text from the times of the apologists that divides the human person into body and soul is Legatio pro Christianis by Athenagoras (see 1.4; 36.2 ). Quite remarkably, Legatio pro Christianis is indebted to Platonism to a far greater degree than Diognetus. Not only did Athenagoras read Plato (see Barnard 1972b, 6-7) and admire him (see Leg. 23.5-10; cf. Geffcken 1907, 213), he was also, as Jacobsen 2014, 82, puts it, "well placed in the Middle Platonic tradition." Malherbe 2014, 2:827, even describes him as a "Christian Platonist." It is worth noting that, though the biography of Athenagoras largely remains a mystery, some of the evidence suggests that he had Platonist affiliations: according to Philip of Side (Hist. Christ. fr. 2; see Heyden 2006, 214-215), Athenagoras "became a Christian while wearing the philosopher's cloak and presiding over the Academy ( $\tau \hat{\eta} \varsigma$

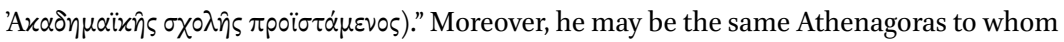

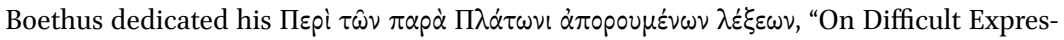
sions in Plato" (Photius, Bibl. 155.100a.19-21 Bekker). Admittedly, this identification is questionable, but not impossible; cf. Zahn 1884, 6o; Barnard 1972a, 16; Dyck 1985, 81. 
6. According to Diogn. 6:5-6, the flesh/body hates the soul, but the soul loves $(\varphi(\lambda \varepsilon i \hat{)})$ the flesh/body nevertheless. This stands in marked contrast to what Maximus says in his Diss. 7.5 (cf. the discussion above): only the wretched soul loves the body; this love will cause nothing but misery. The Gospel of Thomas stresses the unworthiness of the body, which means that love for the body is most certainly out of the question. ${ }^{56}$ In this respect, therefore, Diognetus goes against the Platonist tradition, whereas the Gospel of Thomas agrees with it.

\section{Conclusions}

In this chapter, I have discussed the anthropology of the Gospel of Thomas. The results of my study are as follows. First, while, in my opinion, Patterson's suggestion that the Gospel of Thomas draws on Platonist anthropology is right, I find it unlikely that the Thomasine $\pi \nu \varepsilon \hat{u} \mu \alpha$ is an equivalent of the Platonist vovิs. As I have argued, while it may seem that Philo occasionally identifies vov̂ৎ with $\pi v \varepsilon \hat{\nu} \mu \alpha$, the latter term is always part of the biblical lemma and thus belongs exclusively to the explanandum of the text. In other words, $\pi v \varepsilon 0 \hat{\mu \alpha}$-in a sense that would be synonymous with vov̂_ — did not belong to Philo's philosophical vocabulary and, by inference, is not attested in the Middle Platonist lexicon. ${ }^{57}$

Second, it is unlikely that the Gospel of Thomas adheres to a certain variety of the tripartite anthropology whereby it would consider the soul to be an entity inferior to the spirit. In all likelihood, just like different Thomasine sayings call the corporeal and inferior part of the human being either "body" or "flesh," so also they call the superior and incorporeal part either "soul" or "spirit." As I have argued, the use of the term $\psi v \times \eta$ in sayings 25 and 28 suggests that the

$5^{6}$ Only the soul is worthy of love (Gos. Thom. 25:1). As I have argued above (pp. 8o-81), "your soul" in Gos. Thom. 25:1 means "yourself," which implies that the Gospel of Thomas identifies the soul with the true self of the human person. This notion is in line with the Platonist understanding of the body-soul relationship: "Since a man is neither his body, nor his body

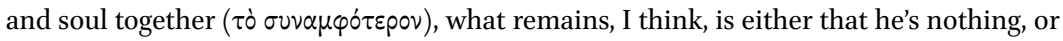
else, if he is something, he's nothing other than his soul" (Pseudo-Plato, Alc. maj. 13oc; trans. D.S. Hutchinson); "For each of us is a soul, an immortal living being locked up in a

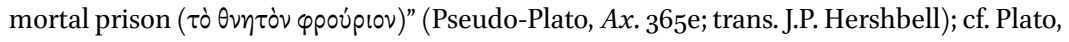
Leg. 959a-c.

57 The only sort of $\pi v \varepsilon \hat{v} \mu \alpha$ that belonged to Philo's philosophical vocabulary is the $\pi \nu \varepsilon \hat{\nu} \mu \alpha$ of Stoic physics (see, e.g., Deus 35). Interestingly, he uses the term $\pi v \varepsilon \hat{\mu} \mu \alpha$ in the Stoic sense in Fug. 134 (pace Burton 1918, 158, 160-161), where he applies to vov s the Stoic definition






Gospel of Thomas envisions the soul as the true self of the human person and the body as an entity that is incidental to a person's existence. Such an antithesis of the body and the soul appears to be identical with that of the body and the spirit in saying 29, which describes the spirit that dwells in the body as the "great wealth" that has taken up residence in "poverty." The hypothesis that the Thomasine "soul" or "spirit" are synonymous receives additional support from my analysis of Gos. Thom. 114:2. As I have suggested, it is likely that the Thomasine notion that men are "living spirits" draws on the creation narrative of Gen 2:7, where God makes Adam "a living soul." The fact that Gos. Thom. 114:2 substitutes the $\psi v \times \eta$ ' of Gen 2:7 with $\pi v \varepsilon v \mu \alpha$ indicates that the Gospel of Thomas does not envision these two terms as significantly different.

Third, it does not seem likely that Thomasine anthropology is indebted either to Tim. $87 \mathrm{c}-89$ a or to later Platonists who commend a balance between the body and the soul along the lines of this Platonic passage. It does not seem possible to reconcile the idea that the body and the soul can and should be in equipoise with the Thomasine contempt for the body. It is much more likely that, according to the Gospel of Thomas, the body and the soul are enemies, and that the Gospel of Thomas favors the soul. This sentiment has close parallels in the Platonist tradition, starting from Plato's Phaedo with its detailed account of the hostile relations between body and soul. As I have argued, it seems that the Platonist body-soul dualism had an impact on the Gospel of Thomas. It is against this background that Thomasine anthropology should be studied.

In the opening paragraph of his handbook, Alcinous defines philosophy as "freeing and turning around of the soul from the body" (Didasc. 1.1; trans. J.M. Dillon). As I have tried to argue, though the Gospel of Thomas is not a philosophical treatise, its understanding of human perfection is not much different from that of Alcinous and other Platonist and Platonizing authors. If we appreciate the Thomasine appropriation of Platonist body-soul dualism, we gain a deeper understanding of the theological orientation of this text and insight into the reasoning behind the sayings that deal with the human compound and its components. 